\title{
An interdisciplinary perspective on the theology of masculinity
}

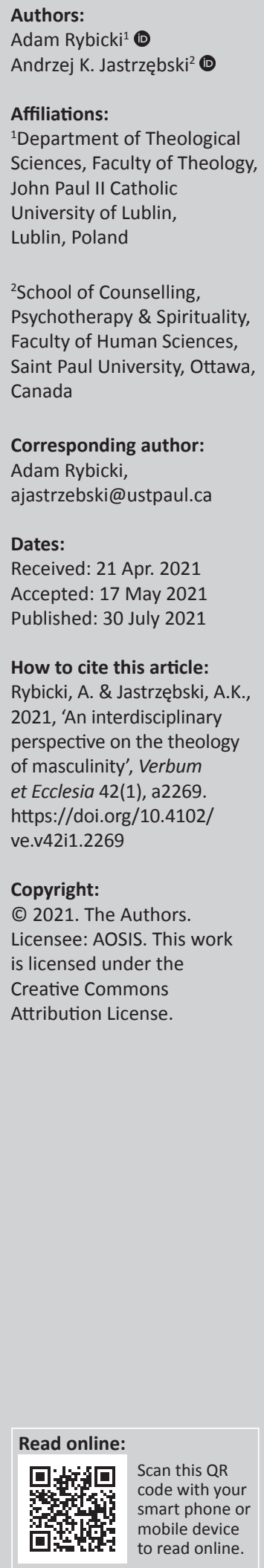

In contemporary academic discourse, there has been a strong tendency to shape theology according to a viewpoint based on the achievements of other sciences, especially those found in philosophy, psychology, sociology and anthropology. This has been particularly illustrated in the issue of masculinity. In this context, a question arises as follows: does theology have something to say to the social sciences? Or, does it only have to submit to them and simply fulfil the role of a commentator? The setting of this study has been the contemporary crisis in understanding masculinity, and the theological reflection that this situation calls for. To address this challenge, we have used a historical-analytical method in which we traced the historical and philosophical underpinnings of the concept of masculinity, with a special focus on modernity, in order to clearly understand the present state of the debate around masculinity. As a result, we have proposed some direction for future theological development, demonstrating that theology may also influence and inspire the other sciences. In conclusion, we have encouraged a deeper collaboration of various sciences that have already developed a reflection on masculinity, whilst avoiding unnecessary biases and simplification; we have sought to establish a better collaboration between feminist movements and theological reflection as well as making use of theology's potential to inspire other sciences such as psychology, sociology and anthropology in this endeavour.

Intradisciplinary and/or interdisciplinary implications: Using such an interdisciplinary collaboration, theology can supply a more positive and hope-giving picture of the contemporary male human being facing an identity crisis, as is demonstrated predominantly in the social sciences. Special attention to this topic has been given in Spiritual Theology.

Keywords: spirituality; masculinity; theology; humanities; social sciences.

\section{Introduction}

The issue of male spirituality is a relatively new research area, although some of its elements were already the subject of empirical research much earlier. These issues were generally related to sex and sexuality (Alfred Charles Kinsey, William Howell Masters, Valen E. Johnson, Angela Pietropinto), the differences between a woman and a man, personality traits (L. Sahuc) and, finally, the area called 'men's religiosity'.

According to Sussman (2012:81-89), technology and (Protestant) theology are the two most important factors that have shaped the understanding of masculinity from the beginning of the 19th century until today. When it comes to the theological aspect, one has to note that, in the Western world, men of the industrial age (but also those of today) were shaped by a specific work ethic, as well as a specific male anthropology, which was derived from the views of the important Protestant theologian John Calvin (1509-1564). According to Calvin, salvation is not accomplished by deeds, but rather by the mysterious process of God's election. The question arose, however, on what basis this choice would be made, and how is God to choose those who will be saved. With the development of commercial society, a concrete answer has appeared: God's chosen ones are those who have achieved economic success through their hard work, savings and resourcefulness. This kind of thinking about men, especially in America, has caused faith to be seen as the path to riches, and those who have achieved it are considered God's chosen ones. This is just one example of how theology can influence both the understanding of masculinity, as well as shape male ethos in society.

The issue of masculinity has not been a research area for long time because masculinity as an anthropological category appeared to be something obvious, natural and indisputable. According to one (Cordes 2002) survey presented in Frankfurter Allgemaine Zeitung in 2001, there were 98 
university departments dedicated to women's issues and not a single department dealing with the problem of masculinity or fatherhood. One can give several reasons why masculinity studies have been underdeveloped up to now.

Firstly, world history was written essentially by men. They focused mainly on the genesis of the world, the laws of nature and the possibilities of technical development and the development of human nature. As a consequence, their reflections were accompanied by a kind of 'gender blindness'. When women began analysing their sexuality and gender issues, they started to point out this bias. Nonetheless, it took many years for men themselves to recognise their own gender as an object worthy of academic enquiry, so that, as the German sociologist Uve Frevert stated, only recently has masculinity become an academic problem, becoming the subject of social, psychological and other research (Frevert 1995).

Secondly, the lack of research on masculinity can also be explained by the fact that issues related to being a man were not interesting for researchers and thinkers, as they seemed to be simple and obvious, automatically inherited and passed down through the generations. Becoming a man was, as one researcher put it, somewhat pessimistic and monotonous (Theweleit 1980).

The third factor was the lack of a catalyst, an element provoking the questioning of the status of masculinity. Such a question was only catalysed by the feminist movement and the contemporary crisis of masculinity and fatherhood. The development of the feminist approach has prompted researchers to deal with masculinity in order to position masculinity in relation to the developing feminist outlook. The crisis of masculinity has become more and more pronounced precisely because of it arising in conjunction with the growing feminist movement, especially its anti-male factions. In this way, interest in the subject of masculinity has been initiated both at the level of reflection (research and publications), as well as in view of specific activities (male movements, meetings of men and various initiatives dedicated to men). The awakening of scientific research with regard to masculinity was aimed at raising awareness and at clarifying the essence of masculinity (Holt 2001).

Fourthly, the modern anthropological sciences do not deal extensively with the issue of the psychological and spiritual separateness of women and men, but are particularly keen on the narrower field of sexuality: psychologists have given this field over to sexologists, as one researcher rightly said, which made the sexual aspect of femininity and masculinity the main focus of science, especially through the lens of all possible pathologies. However, it has to be noted that this is only a small part of the broad issue of masculinity and femininity.

Fifthly, according to some theories, masculinity in its old, traditional meaning no longer exists. According to this approach, in taking up this issue, one is analysing a historical idea, as Merleau-Ponty expressed it, so it is not even worth doing (Evdokimov 1994:22-25). The view about 'non-existent masculinity' includes theories about many masculinities, because today we are talking more about 'masculinities' rather than about one 'masculinity'. We can find military, Jewish, gay, postmodern, inclusive, lumbersexual, sticky (Berggren 2014:231-252), African (Ratele 2013:133-156, 2014:30-44) and toxic masculinity, to name but a few. These typologies are constantly crumbling in academic discourse and the media (Śmieja et al. 2018:11-24).

In this article, we intended to demonstrate that a new meaning of masculinity, inspired by theological anthropology, can be developed. To achieve this goal, we analysed selected theories regarding masculinity and their historical origins, drawn from philosophy, sociology, psychology and theology. Finally, we synthetically proposed a set of directions in which theology could become an inspiration to other sciences regarding the understanding of masculinity.

\section{Historical background Ancient times}

However, it is worth starting our analysis with reflections from the ancient world because it has left the most lasting mark on our understanding of masculinity, and it was the ancient Graeco-Roman culture that was first applied to Christian attempts to answer questions pertaining to the understanding of masculinity.

Related to the so-called Western culture perception of man, the concept of masculinity and femininity was shaped, on the one hand, by the Greek tradition, and on the other by the Judeo-Christian. The fruits of the encounter between the philosophy of ancient Greece and the Biblical thought of the Old Testament and New Testament in antiquity are still present in our own times. Plato was convinced about equality between a woman and a man at the level of intellectual capacities. He also proposed that this equality should be provided in the sphere of upbringing and social roles, because thinking in categories of the state required the subordination of many areas of the social life of citizens to the common good. And although his views are interpreted today in the light of feminist postulates, Plato did not found his claims on respect for women's dignity, but rather on a certain form of pragmatism, as exemplified by the following words: 'a woman is suitable by nature for all actions as a man, only in all of them a woman is weaker than a man' (Richards 1966:455).

Plato was also far from the cult of 'masculinity'. Later, Nietzsche (1998) as noted by Blackburn (2008) complained that there is no male 'will of power' in Plato's philosophy, no striving for advantage, thirst for life, etc. However, as noted by Blackburn, Nietzsche simplifies the issue: Plato does not condemn the bravery and values embedded in the male part of the soul, but wants it to be properly directed. He also wants to modify slightly our concept of 'courage', separating it from the violent will of power, military spirit or desire for 
glory in war. Courage is more like solidarity and fortitude (as exemplified by Socrates) and is not the same as arrogance because it requires the ability to make a clear assessment of the situation. Consequently, 'bravery' should be distinguished from masculinity, which interpreters of Plato do not always succeed in distinguishing, especially when they raise the issue of equality between men and women in Plato's Republic (Blackburn 2008).

Conversely, Aristotle, based on his observations of nature, maintained a view of the biological superiority of men. His views are sometimes considered typical of the androgynous view of a woman and a man. Masculinity is the 'norm' for him, whilst a woman is a deviation from this norm, even a defect. Aristotle's views are nowadays considered to be the beginning of the reflection on women and men in the context of highlighting their differences, both at the level of biology and the psyche and of social roles (Babik 2008:83-99).

Peter Brown (1988:33-34), in his monumental work The Body and Society, Men, Women and Sexual Renunciation in Early Christianity, described the understanding of masculinity in Christian circles in the period before the missionary journeys of Saint Paul in the years 40-50 until the period after the death of Saint Augustine in 430. Although the main focus of his research was on sexuality and sexual abstinence, his research brought to light certain features of the understanding of masculinity at that time. Based on the writings of Galen, Polemon and Lucian, Brown indicates that masculinity was associated with a specific 'warmth', which was understood as a life breath. This category guaranteed being a man, and the loss of this heat could threaten a 'slip into femininity' or a 'primary undifferentiating'. The small-town nobles from the 2nd century looked at each other with hard, sharp eyes. They watched this or that, reacted to the rhythm of one's speech and carefully listened to the sound of one's voice (Brown 1988:510). However, nothing could reveal the loss of this hot masculine energy, the weakening of self-control and the level of refinement in behaviour that made a man a stable master of the world. Interestingly enough, in a world in which men patronised tasteless bloody games or imposed harmful penal codes on the lower social layers, they were required to maintain restraint and self-control in direct relations (e.g. with slaves), to be gentle and even fatherly. Although the entire slave system was based on cruelty, men were often criticised for violence towards slaves, outbursts of rage, etc., because this kind of restraint was considered 'feminine' (Brown 1988:5-10).

This ancient image of masculinity is best known from the literary works of that time. It is worth emphasising that, be they the works of Homer, Plutarch, Aristophanes or Plato, one can find a relatively consistent image of masculinity in all of them. Despite their extension over time, these ancient authors were consistent in presenting the ideal of masculinity and this consistency is worth emphasising. More than 1000 years elapse between Homer (8th century BC) and the end of the Ancient period and, despite various social changes, the ancient Greeks retained a consistent picture of masculinity. It is an image built on the opposite of gender, testifying to a deepened reflection on the essence of humanity and masculinity. However, the question that arises in this context is as follows: do they not present an ideal and not actual male practices and behaviours? Is it possible at all to reconstruct the image of masculinity at that time on the basis of the available sources, if the authors possibly describe only the pattern, and not real men? (Corbin, Courtine \& Vigarello 2011). A similar problem arises by describing the ethos of chivalry of the late Middle Ages, when the actual practices and behaviour of knights deviated substantially from the ideal sung about in poems. Despite this, the stereotype of a knight has survived into our times based on songs rather than descriptions of the real life of chivalry. J. Huizinga referred to it as an aesthetic ideal, built of colourful fantasies and lofty sentiments (Huizinga \& Hopman 1927).

\section{The modern period}

Along with the social changes of the past centuries, the social position of women has changed, which fuelled interest in feminist issues, both in the area of politics as well as in sociology and philosophy. In the context of philosophical considerations, thinkers such as Descartes, John Lock and Jean Jacques Rousseau come to the fore. However, in the mid-1980s, scientist-humanists, writing about humans and their problems, considered men to be 'asexual abstracts'. Gender issues and the differences related to them were completely ignored. Generally speaking, one would not find the answers to the questions pertaining to who is man and what is masculinity from the philosophical point of view. In fact, only psychology, pedagogy or sociology answered them. In the final analysis, the issue of masculinity undoubtedly owes its development to feminist research (Uliński 2001:316-317).

According to Jean Jacques Rousseau, a man is not someone whose personality develops spontaneously over time. Raising a boy involves tedious work on several levels. One should start by enabling him first to develop physically; this should be enriched by reflection on the world of things, and only then can one teach him how to function in the world of people. The next elements forming the male personality should be travelling and performing various works, preferably crafts. Life amongst people, combined with work, teaches justice, and respect for work forces reflection on the customs prevailing in a given country. Only this can be the foundation of spirituality, religious reflection and a context for the shaping of a rational faith in God. A boy prepared in this way is to become a human being who is active, thoughtful, loves freedom but also justice (Rousseau 2008).

In 1764, Immanuel Kant published his work Observations on the Feeling of the Beautiful and Sublime (Kant 2011), where he ascribed to men 'sublime disposition' and wisdom, whereas to women greater freedom and the truth of emotional life and the beauty of her disposition. Kant's concept of male 'sublimity' should be understood as being synonymous with such values or images as friendship, great depth, high 
oaks, night, old age, reason, courage, nobility, etc. Whilst we learn beauty sensually and directly, sublimity demands some reflection. Kant, like Fichte and Hegel, alluded to Rousseau, modifying and enriching his thought (McQuillan 2011:438-441)

Pelamatti and Peluso (2004) pointed to the first historically documented manifestation of male concern over their own identity and, thus, the first undertaking of some basic reflection on this subject, which was Preziosism, that is, a movement from the turn of the 17th and 18th centuries which was initially a typically feminist French trend (from the Italian preziosa 'valuable'). This movement amongst women meant a desire to destroy the dominant role of man, and his total subordination to woman. Because it was also concerned with putting an end to men's brutality, arrogance and pretentiousness, on the one hand, it therefore aroused unbelievable resistance amongst men (e.g. in England), but on the other hand, the views of this movement began to please some of them. Therefore, there were attempts amongst men to adopt these views: they adopted women's ways of dressing, used lipstick, perfume and long wigs.

In relation to masculinity, the figure of Sigmund Freud is most often associated with the so-called Oedipus complex. Originally, a bisexual boy must develop male traits, especially aggressiveness, but from the beginning of his life, he is associated with his mother as she is the closest person to him. Because she is of the opposite sex, he is jealous of her favour and feels his father's presence as a rival. He focuses his hatred on his father, wanting to take away his father's favours. However, he is afraid of retaliation on the part of his father ('castration complex'), and recognises his authority to finally identify with him, creating a male personality and a male superego. The Oedipus complex ends and breaks down when it comes to the formation of the male character and male superego (Freud 1990). The idea of the Oedipus complex, especially initially, gained many followers who saw in it the key to understanding many male behaviours. With time, however, this concept was questioned and undermined. Modern researchers, such as Eugen Michael Jones, explicitly state that Freud's claim that 'all men' desire sexual relations with their mothers (or sisters) is a powerful rationalisation and projection of the fact (and guilt associated with it) that Freud himself had an intimate relationship with his sister-in-law, Minna Bernays (Jones 1993:153ff.).

Criticism of the Oedipus complex, like of psychoanalysis in general, pointed to its reductive view of man (Kugelmann 2011). One of the most outstanding critics of psychoanalysis, psychiatrist and philosopher Rudolf Allers noted the undoubted merits of Freud in his book The Successful Error, but also showed his extremely materialistic and hedonistic vision of man and, in this sense, called psychoanalysis 'a heresy'. According to Allers, the distorted image of a man also influenced the formation of the psychoanalytical method, which is largely based on free associations and their interpretation. In this context, the male Oedipus complex can neither be proved nor can be made the key to the understanding of male nature. The biggest criticism, however, touched on the philosophical aspects of psychoanalysis. Allers (1940:168) argued that a philosophy (and 'no psychology exists without philosophy') that questions free will, bypasses the spirituality of the soul and knows no purpose other than pleasure 'is blind to the true nature of the human person' (Allers 1940:199-200).

According to Jung (Read et al. 1953-1976), a man carries both Animus (masculinity) and Anima (femininity) archetypes. 'Masculinity' should be associated with all shades of the Greek concept of Logos, namely, Strength, Will, Action, Word and Sense, rational differentiation, ordering, awareness and spirituality, whilst 'femininity' is closer to matter, nature and is sensitive to interpersonal relationships, practical reason, irrationality, uncriticality and passivity. When it comes to spirituality, Anima shows underdevelopment, disability, even primitivism:

[I]n men, Eros, the relational function, is usually less developed than Logos. In contrast, a woman's Eros is an expression of her true nature, whilst Logos is often a regrettable accident, wrote Jung (The Syzygy, CW 9ii, par. 29; Tacey 2012).

Max Scheler, as a representative of phenomenological anthropology, sought the essence of man in all of its phenomenal aspects, departing from earlier scientific and psychological methods. In terms of the human phenomenon, research on the phenomenon of sexuality could not be lacking (nor in the context of the growing aspirations for emancipation at that time). According to Scheler, the whole of European anthropology is a masculine idea, as evidenced by the same word for human and man in many languages, which is why, when woman aspires to the ideal of man understood in this way (i.e. masculine), she becomes a 'monkey (resemblance) of man' (Scheler 1995:173-195).

\section{Modern Christian thought}

The end of the 19th century, which demonstrated, amongst other things, the intensification of the emancipation movements, also caused some creative anxiety in Christian thought. It must be admitted that emancipation received support from atheist and agnostic-liberal environments, but it became increasingly clear to Christian thinkers that one could no longer speak about certain aspects of faith and spirituality without taking into account the personality differences between women and men. The spirituality of men was not the point of interest at the time, because in those days Christian spirituality was predominantly masculine. As for the ethos and spirituality of women, Edith Stein was one of the first to address this issue. Her studies, based on the theology of Saint Thomas and the philosophy of Edmund Husserl, may be representative of the Christian thought of that period. Although a woman plays a major role in her philosophical and pedagogical considerations, Stein also often spoke about men. According to her, a man identifies with his body much less than a woman. He cares less for his body and is less concerned about the changes that occur in it. 
Therefore, he can be more focused on his tasks (onedimensional), which also means that his development is onesided, whilst a woman embraces the 'whole'. Other male characteristics shown by Edith Stein are primarily in relation to the Beruf ('occupation' in German, but also 'calling') of men and women. The tasks to be performed by men should be different from those belonging to women (Calcagno 2016).

The Eastern Christianity theologian Paul Evdokimov (1994) published a work entitled Woman and the Salvation of the World. According to this Orthodox thinker, the biblical description of the creation of man is the original archetype of all humanity that speaks of the coexistence and difference between a woman and a man. The separation of sexes does not come down to the physiological or psychological level, but reaches much deeper, into the sphere of the spirit, penetrating to the very foundations which constitute human nature. By falling into original sin, the category of 'communion' between men and women was replaced by the category of 'opposition'. Because the religious principle of humanity comes to the fore through a woman, social deviation from feminine traits for men (see Western civilisation) therefore leads to spiritual nihilism and despair.

One of the most momentous ideas of Evdokimov's work is the metaphysical and spiritual dimension of the role of a woman ('appropriate help' - Gn 2:18) towards a man. She not only 'helps' him in worldly matters, in dealing with functioning in this world, but also directly protects him from degradation; she can transform his destructive instinct characteristic for men - into an affirmation of life. In his theory, the male is associated with the Logos, the Son, and the female with the Holy Spirit. Man is related to the hypostasis of the Logos, the male aspects of divine energies, whereas the female is associated with the hypostasis of maternity, Theotokos (Phan 1990:53-66).

\section{The crisis of masculinity in contemporary research}

Masculinity as a social construct has recently become a well-known subject of research. Even more recently, neurobiological research has shed new light on our understanding of the intrinsic differences between the sexes (Sax 2007).

Referring to contemporary research and reflection on masculinity, Babik noticed that their results create two opposite poles: on the one hand, the idea of gender rivalry is emphasised, whilst on the other there is a postulate to level out differences, to unification, to a kind of one human 'gender'. Both poles, of course, have some extremes. The competitive approach that was at the beginning of the formation of women's and feminist movements led women to a kind of 'fight against the male world'. Unification, in turn, means undermining the foundations and purpose of gender diversity (Babik 2008:95). In trying to address this dilemma, Babik noted that both extreme views on the subject of men and women face the following difficulty: modern science, when dealing with the essence of masculinity focuses on its manifestations as studied via the empirical science method (sometimes the reduction occurs only in the biological dimension), whilst, as Sieg stated, the truth about man has always eluded these teachings and requires deductive thinking (Sieg 1996:110).

The research of Joachim Bodamer shows the erosion and even degeneration of contemporary man's religiosity: belief in grace, action and God's love were replaced by trust in the perfection of the technique and the strength of progress. This erosion is not so much a desire to fight religion as much as total indifference: modern man, sociologically speaking, has become not so much anti-religious as non-religious. Nihilism, of course, caused men's ability to pray, meditate and other religious practices to disappear, levelled the benchmarks of moral principles and questioned categories such as one's conscience, one's sense of responsibility before God and even one's sensitivity to the meaning of life and death. Comparing these phenomena to the biological dimension, Bodamer stated that a certain 'soul organ', which served to contact God, degenerated because of its 'inaction' and finally disappeared (Bodamer 1982:48-64). In such a religious (and pessimistic) picture of man thus outlined, the Bible becomes an inaccessible, incomprehensible book or else is seen as a collection of messages that are merely a human message. In the man's world, religious emptiness is filled with the glorification of himself and his own desires. Values such as work, progress, fame or wealth take on religious features, become supreme values and act as a substitute for religion, destroying man and leading to the destruction of both the individual and entire societies.

Joseph A. Vandello and colleagues have performed five empirical studies on manhood. The outcome of this research has demonstrated that manhood, unlike womanhood, is perceived as a precarious state and requires continual validation. Consequently, the authors argue that men feel threatened by any challenges to their masculinity. Certain behaviours typically associated with men, such as physical aggression, may be caused by this anxiety. The researchers discovered that, amongst the participants of the studies, there was a shared conviction about the precarious nature of manhood and a propensity to define manhood by social proof rather than by biological markers. Moreover, the study demonstrated that, in case of feedback indicating genderatypical performance, men will experience elevated feelings of threat and that the threat of the manhood of men activates thoughts about physical aggression (Vandello et al. 2008).

Womanhood is commonly considered to be a natural phenomenon. Somehow, biology itself makes it clear and efficient that she will grow into a healthy woman. It is more likely that the female will become a mature woman than a male a mature man. Contrary to womanhood, manhood seems to be less natural. It faces the challenge of social evaluation. This gives the impression that manhood does not exist within a man and he must go and courageously search 
for it. Maybe this is because male nature is oriented towards extremes. Both as a behaviour and a status, manhood must be learnt, earned and proven in the process of man's growth. Moreover, manhood is not so much a status to be achieved, but rather a reputation to be maintained and, because of this, it can possibly be lost. A failure to properly develop one's manhood results in the infamous phenomenon of 'perpetual adolescence'. Across cultures, manhood has been associated with three essential qualities that have to be achieved: procreation, provision and protection, also called the three Ps of manhood (Stanton 2019:26-30).

Stanton summarises the state of manhood in contemporary society in the following points:

1. 'Manhood must be taught, and it can only grow in the direction of procreating and providing for and protecting one's wife, offspring, and the surrounding community. A true man produces more than he consumes and learns to seek the good of others more than his own.

2. Thus, true masculinity is not and cannot ever be toxic. Masculinity is a personal and social virtue. Those who use the word "toxic" are confusing masculine with macho and male pathology.

3. Manhood does not exist in passivity or stasis. It exists only in action.

4. Manhood is never assumed. It must be demonstrated and proven.

5. Healthy manhood is largely centered in what a man does and does not do with his sexuality and with the weakest and most vulnerable around him.

"It is true that women created humanity, but only men can create manhood" (Margaret Mead).

6. The crafting of manhood is not only essential to every society, but is the foundation upon which society is built. This is not because men are more powerful than women, but in many ways because the opposite is true.

7. Women establish and maintain civilization by their expectations of and demands upon males, beginning with their manners and their sexuality'. (Stanton 2019:3,30)

\section{Contemporary theological approach}

Contemporary theological enquiries about masculinity arose on the basis of responses to the feminist wave of interest in femininity. However, feminism has created not only a new image of women, but also new interpretations of masculinity. Contemporary male theology and male spirituality were born in the context of responses to feminist postulates on this subject:

1. Theology can reconcile biblical (and also biological) essentialism and gender 'fluidity'. The biblical image of God as the Potter (see, e.g. Sir 33:13; Is 29:16) is invoked in theology in the context of the fatherhood of God. God is seen as the Creator and the creation of man as a permanent process. The biblical teaching about God's mercy revolves around the two poles, male and female, and corresponds to certain psychological observations. It may turn out that the influence of the father and mother on the development of boys' masculinity, studied ever deeper, will more accurately reflect the metaphor of Godthe-potter, of God-rich-in-mercy, who, through the parents, like a potter's hand, shapes the first foundations of the child's personality. Theological reflection remains in fruitful dialogue with psychological and sociological research on the value of the influence of the mother and father on the formation of the male personality. The creation of humans by God, with the idea that they should be a woman and a man (Gn 1:27), does not exclude free will or co-operation with the grace of their identity received by the Creator. In a word, theological essentialism does not exclude freedom, and the fact of creating a man as a man does not deprive him of the possibility, or even the vocation, of shaping his own masculinity. Therefore, one cannot agree with Bauman's statement that the discovery, acceptance and possession of the identity given to men are tantamount to the lack of a need to reflect on it (Bauman 1993).

The theology of masculinity rooted in the Bible emphasises the fact that, in the biblical first account of creation, a man is created immediately as a male and a female, whilst the second description provides an interesting distinction: the first human being, a adam, created from the dust of the earth, is only defined as a man from the moment of the creation of a woman ('î̌s). In fact, when God speaks the first words about loneliness, there is no man or woman yet, there is only man, a human being, $\bar{a} d \bar{a} m$. There is no biblical basis for believing that the separation of a man is a mandate to exercise absolute power, whether over the natural world or over a woman (Arcimowicz 2003). Whilst contemporary culture tends to blur gender differences and halt the process of separation (Williams 2017), the Church upholds its essential importance (Congregation for the Doctrine of the Faith 2004): both men and women are to seek their separate identities in order to complement each other. According to certain theological perspectives, the two genders cannot be seen as complementary parts. Each person called by God is independent and complete. Each of them develops their own personality, as well as ontic and moral holiness. However, it should be emphasised that, in their existence, they are compatible (compliance means existence together in harmony) and not complementarity. A. Scola develops this idea using the term 'reciprocity', which is symmetrical and leads to the discovery of a mutual gift (Tatar 2012:191-198). In this way, theology reconciles the separateness, the fullness of humanity and the mutual complementarity of women and men.

2. There is a theological view of patriarchalism that deviates from critical feminist assumptions and is based on the 'patriarchal authority of God', assuming such elements as dualism, meaning distinguishing between transcendence and God's immanence, which allows God, whilst retaining absolute power, to provide a great space of freedom for man. God shows man his place in the hierarchy of beings. Therefore, no male power is ever 
absolute. Only God has the power to fulfil his will without limit; therefore, no man can usurp the right to omnipotence. There is also loneliness, or some kind of separation and, in the case of God, transcendence towards those over whom power is exercised (Culbertson 1992). These elements of patriarchal theology can be applied to masculine spirituality, pointing to both its opportunities and its threats. It seems that the issue of exercising power by men is extremely complex, because it contains many ambivalent elements. However, the teaching of Christ on the power as service (cf. Jn 13:1-15) leaves no doubt as to the function and positive character of the exercising of power by men (James 1996).

3. The theology and biblical figures of men are an inexhaustible source of inspiration in the search for the identity and spirituality of men in the 21st century. Based on biblical essentialism, it is clearly visible that, on the one hand, identity is a gift (talent), and even a vocation that man receives from the Creator; on the other hand, there is a wide margin of freedom in the forms of the realisation of this gift and in the ways of responding to this vocation. Certain biblical patterns of masculinity are universal, proven over the centuries and bear fruit. Reaching for them in the present day is not a safe escape into conservatism, but rather is setting ourselves the difficult task of realising universal male characteristics and values in a changing world, in new sociocultural conditions and a changing mentality.

\section{Conclusions}

Nowadays, there is a common conviction that we should rethink masculinity. Manhood has been declared to be in danger from the challenges coming from the modern feminist movement. As a result, there have been a lot of men who have changed, but not from their own initiative - it was rather a response to women's changes. Traditionally, for a man to be successful, he would need to do three things well: procreate, provide and protect. Anthropological research informs us that these three pillars of manhood have been recognisable in every culture over the millennia. Men were expected to produce offspring, to provide for their families and tribes and protect them - and the more so, the better (Gilmore 1990).

In our contemporary society, neither procreation nor a major single income on the part of men is significant because women are already independent in many ways. Furthermore, in a time of terrorism and roadside bombings, protection by a single man is no longer possible. Present social developments dramatically question the traditional three pillars of being a man. Although they have framed manhood and men's roles in society for centuries, nowadays they are no more as valuable as before (Daloz 2011:75-83).

There is no doubt that both nurture and nature are important, but in our times, the psychological approach to the formation of masculinity is more important. One of the most important psychological insights regarding masculinity has come from a woman informed by object relations theory. Dorothy Dinnerstein has suggested that the tension between the sexes is because of the simple fact that mothers are women. In essence, for every human being, the central early relationship is a relationship with a woman. It is in this relationship that we form our earliest intense and wordless feelings towards existence (Dinnerstein 1976:33). The effect of this process differs regarding boys and girls. Boys need, at some point, to separate psychologically from their mothers, whereas girls need only to identify with their mothers (Daloz 2011:75-83).

One of today's major problems is the fact that there are too many fathers missing from their sons' lives. More than $40 \%$ of all males have been raised in homes without a resident father (Salzman, Matathia \& O'Reilly 2005). The heroic efforts of mothers to compensate for this missing male figure have not protected many boys from the psychological damage called the 'connectivity deficit'. Young males spend much of their boyhood attempting to overcome this sentiment. They try to justify their separateness from the feminine. The usual response to this threat of psychic annihilation is either 'fight or flight', and this is illustrated by the form of the two traditional heroic archetypes: the armoured man and the eternal boy. Each one represents one end of the spectrum, and each one shows up in most men (Daloz 2011:75-83).

The theology of masculinity requires a deeper, biblical personalistic reading, rather than one based on the cultural aspects of some currents of theology. The theology of masculinity outlined in this way does not have to stand in complete opposition to other points of view (e.g. feminist, those resulting from gender ideology, etc.), for reasons often posed on the opposite extreme. Rather, the theology of masculinity complements and justifies some of the postulates and achievements in the other humanities, an example of which is the equal dignity of a woman and a man, the understanding of power as a service or the theology of vocation as a call to become men, meaning their permanent transformation, their struggle with their own weaknesses, etc. On the other hand, other humanities and social sciences can significantly supplement theological research on masculinity. Interdisciplinary reflection may show the way to the implementation of the theological postulate of spiritual and personality development, fulfilling social roles (e.g. paternity), as well as the moral and ethical aspects of masculinity.

\section{Acknowledgements Competing interests}

The authors declare that they have no financial or personal relationships that may have inappropriately influenced them in writing this article. 


\section{Authors' contributions}

A.R. was responsible for the concept and theological part of the article. A.K.J. was responsible for the social sciences part as well as the first English draft of the article.

\section{Ethical considerations}

This article followed all ethical standards for research without direct contact with human or animal subjects.

\section{Funding information}

This article is part of a project funded by the Ministry of Education and Science, Republic of Poland, 'Regional Initiative of Excellence' in 2019-2022, 028/RID/2018/19.

\section{Data availability}

Data sharing is not applicable to this article as no new data were created or analysed in this study.

\section{Disclaimer}

The views and opinions expressed in this article are those of the authors and do not necessarily reflect the official policy or position of any affiliated agency of the authors.

\section{References}

Allers, R., 1940, The successful error: A critical study of Freudian psychoanalysis, Shed \& Ward, London.

Arcimowicz, K., 2003, Obraz mężczyzny w polskich mediach, Gdańskie Wydawnictwo Psychologiczne, Gdańsk.

Babik, M., 2008, 'Istota męskości', in J. Augustyn (ed.), Duchowość mężczyzny, pp. 83-99, WAM, Kraków.

Bauman, Z., 1997, Postmodernity and its discontents, New York University Press, New York, NY.

Berggren, K., 2014, 'Sticky masculinity: Post-structuralism, phenomenology and subjectivity in critical studies on men', Men and Masculinities 17(3), 231-252. https://doi.org/10.1177/1097184X14539510

Blackburn, S., 2008, Plato's Republic: A biography, Atlantic Monthly Press, New York NY.

Bodamer, J., 1982, Der Mann von heute, 4th edn., Herder, Freiburg im Breisgau.

Brown, P., 1988, The body and society, men, women, and sexual renunciation in early Christianity, Columbia University Press, New York, NY.

Calcagno, A., 2016, Edith Stein: Women, social-political philosophy, theology, metaphysics and public history: New approaches and applications, Springer, Cham.

Congregation for the Doctrine of the Faith, n.d., Letter to the bishops of the Catholic Church on the collaboration of men and women in the church and in the world viewed 31 May 2004, from http://www.vatican.va/roman curia/congregations/ cfaith/documents/rc con_cfaith_doc 20040731 collaboration_en.html.

Corbin, A., Courtine, J.J. \& Vigarello, G. (dir.), 2011, Histoire de la virilité: Tome 3, La virilité en crise? Le xxe-xxie siècle, Éditions du Seuil, Paris.

Cordes, P., 2002, Die verlorenen Väter, Herder, Freiburg im Bresgau.

Culbertson, P., 1992, The new Adam: The future of male spirituality, Fortress Press, Minneapolis, MN.

Daloz, L.A.P., 2011, 'Mentoring men for wisdom: Transforming the pillars of manhood', New Directions for Adult and Continuing Education 131(Fall), 75-83. https://doi. org/10.1002/ace.423
Dinnerstein, D., 1976, The mermaid and the minotaur, Harper \& Row, New York, NY.

Evdokimov, P., 1994, Woman and the salvation of the world, St Vladimir's Seminary Press, Crestwood, NY.

Freud, S., 1990, Beyond the pleasure principle, W.W. Norton \& Company, New York, NY. Frevert, U., 1995, Mann und Weib, und Weib und Mann: Geschlechter-Differenzen in der Moderne, Beck, München.

Gilmore, D., 1990, Manhood in the making, Yale University Press, New Haven, CT.

Holt, B.P., 2001, The story of Christian spirituality: Two thousand years from East to West, Lion Publishing, Oxford.

Huizinga, J. \& Hopman, F.J., 1927, The waning of the middle ages: A study of the forms of life, thought and art in France and the Netherlands in the XIVth and XVth Centuries, E. Arnold, London.

James, D.C., 1996, What are they saying about masculine spirituality, Paulist Press, New York, NY.

Jones, E.M., 1993, Degenerate moderns: Modernity as rationalized sexual misbehavior Ignatius Press, San Francisco, CA

Kant, I., 2011, Observations on the feeling of the beautiful and sublime and other writings, Cambridge University Press, Cambridge.

Kugelmann, R., 2011, Psychology and Catholicism: Contested boundaries, Cambridge University Press, Cambridge.

McQuillan, C., 2011, 'Immanuel Kant: Immanuel Kant: Observations on the feeling of the beautiful and the sublime and other writings', Philosophy in Review 31(6), 438-441.

Nietzche, F., 1998, On the genealogy of morality, M. Clark \& A. Swensen (transl.), Hackett, Indianapolis, IN.

Pelamatti, L. \& Peluso, A., 2004, Gonna e pantaloni. Maschile e femminile nella coppia, San Paolo Edizioni, Cinisello Balsamo.

Phan, P., 1990, 'Gender roles in the history of salvation: Man and woman in the thought of Paul Evdokimov', Heythrop Journal 31(1), 53-66. https://doi. org/10.1111/j.1468-2265.1990.tb01151.x

Ratele, K., 2013, 'Masculinities without tradition', Politikon: South African Journal of Political Studies 1(40), 133-156. https://doi.org/10.1080/02589346.2013.76 5680

Ratele, K., 2014, 'Currents against gender transformation of South African men: Relocating marginality to the centre of research and theory of masculinities', Norma: International Journal for Masculinity Studies 9(1), 30-44. https://doi.org/ 10.1080/18902138.2014.892285

Read, H., Fordham, M., Adler, G. \& McGuire, W., 1953-1976, The collected works of C.G. Jung, 20 vols., Bollingen Series XX, transl. R.F.C. Hull, Princeton University Press, Princeton, NJ.

Richards, I.A., 1966, Plato's Republic, Cambridge University Press, Cambridge.

Rousseau, J., 2008, Collection complète des CEuvres de J. J. Rousseau. Émile, ou de l'Éducation, S. éd., Genève.

Salzman, M., Matathia, I. \& O'Reilly, A., 2005, The future of men, Palgrave Macmillan, New York, NY.

Sax, L., 2007, Boys adrift, Basic Books, New York, NY.

Scheler, M. (ed.), 1995, 'Zur Idee des Menschen', in Gesammelte Werke, vol. 3, pp. 173-195, Francke Verlag, Bern-München.

Sieg, J., 1996, Filozofia a świat współczesny, WAM, Kraków.

Śmieja, W., Matuszek, D., Mazurkiewicz, F. \& Kłosińska, T.K.K., 2018, ‘Obmapywanie męskości. Z Raewyn Connell rozmawiają', in A. Dziadek (ed.), Formy męskości 3 , pp. 11-24, Wydawnictwo Instytutu Badań Literackich PAN, Warszawa.

Stanton, G.T., 2019, 'Manhood is not natural: Why it's in bad shape \& how to recover it', Touchstone: A Journal of Mere Christianity 32(3), 26-30.

Sussman, H., 2012, Masculine identities: The history and meanings of manliness, Praeger, Santa Barbara, CA.

Tacey, D.J., 2012, The Jung reader, Routledge, London.

Tatar, M., 2012, 'Structure of man in the biblical act of creation', Analecta Cracoviensia 44, 191-198. https://doi.org/10.15633/acr.15

Theweleit, K., 1980, Männerphantasien, Rowohlt, Reinbek bei Hamburg.

Uliński, M., 2001, Kobieta i mężczyzna. Dzieje refleksji filozoficzno-społecznej, Aureus, Kraków.

Vandello, J.A., Bosson, J.K., Cohen, D., Burnaford, R.M. \& Weaver, J. R., 2008, 'Precarious manhood', Journal of Personality and Social Psychology 95(6), 1325-1339. https://doi.org/10.1037/a0012453

Williams, M., 2017, Self-concept: Perceptions, cultural influences and gender differences, Nova Publishers, New York, NY. 